\title{
Technical Note: Effect of substrate drying method on in vitro dry matter disappearance in moose
}

\author{
WILLIAM E. FABER, ÅKE PEHRSON, AND PETER A. JORDAN
}

\begin{abstract}
Authors are currently graduate student, research scientist and associate professor. WEF and ÅP are located at the Grimsö Wildlife Research Station, Dept. of Wildlife Ecology, Swedish University of Agricultural Sciences, S-730 91 Riddarhyttan, Sweden; and PAJ is located at the Dept. of Fisheries and Wildlife, College of Natural Resources, University of Minnesota, 200 Hodson Hall, 1980 Folwell Ave., St. Paul 55108-6124.
\end{abstract}

\begin{abstract}
One identified potential source of error in nutritional evaluations using the in vitro technique is the drying method used on test substrates. This study was conducted to determine what effect, if any, different drying methods have on the dry matter disappearance of 4 browse species in moose (Alces alces L.) inoculum. Browse species were Scots pine (Pinus sylvestris L.), birch (Betula pendula Roth, Betula pubescens Ehrh.), willow (Salix spp.), and sweetgale (Myrica gale L.). In addition, we determined the effects of drying method on neutral detergent fiber (NDF), acid detergent fiber (ADF), and acid detergent lignin (ADL) concentration of the browse species. Each species was either freeze-dried $\left(-40^{\circ} \mathrm{C}\right)$ or oven-dried at $35^{\circ}, 60^{\circ}$ and $105^{\circ} \mathrm{C}$, respectively. High drying temperatures significantly depressed $(P<0.0001)$ in vitro dry matter disappearance (IVDMD) in all browse species tested except of Scots pine. High temperatures also reduced NDF $(P<0.05)$ in all the species, while ADF and ADL were elevated $(P<0.05)$ in all species except Scots pine. We conclude that freeze-drying is the most preferable method to be used on forage and browse samples being evaluated for nutritional quality.
\end{abstract}

Key Words: drying temperatures, Alces alces L., forage quality, dietary fiber

The in vitro technique is widely used for evaluating the nutritional quality of forage and browse for both domestic and wild ruminants. It is an especially important technique in wildlife research due to the difficulty involved in performing digestion studies in vivo. However, it is important to know potential sources of error involved when using the in vitro techniques. Previous research has shown that air- $\left(0^{\circ}, 25^{\circ} \mathrm{C}\right)$ or oven-drying $\left(55^{\circ}, 65^{\circ}, 100^{\circ} \mathrm{C}\right)$ depressed in vitro disappearance estimates for oak browse diets in goats (Capra hircus L.) (Nastis and Malechek 1988). Other research (Acosta and Kothmann 1978, Engels et al.

\footnotetext{
Research was funded in part by the Swedish Institute, and the private foundations "Stiftelsen Oscar och Lili Lamms Minne" and "Olle och Signhild Engkvists Stifelser". Authors wish to thank T. Palo, J.A. Pfister and 2 anonymous referees for improving the manuscript, $H$. Andrén for assistance in statistical analysis, and B. Sundholm for lab assistance.

Manuscript accepted 5 Feb. 1995.
}

1981, Burritt et al. 1988) found air- or oven-drying depressed in vitro disappearance of esophageal extrusa. This depression is linked to changes in the fiber fraction (neutral detergent fiber (NDF), acid detergent fiber (ADF), and acid detergent lignin (ADL) concentration) resulting in nonenzymatic browning reactions (Hodge 1953) which produces artifact lignin (Van Soest 1965) and reduces Dry Matter Disappearance (IVDMD). This suggests that drying methods other than freeze-drying may compromise the value of IVDMD to estimate nutritional quality of forage species.

At the Grimsö Wildlife Research Station (GWRS), use of the in vitro technique is an important tool in the evaluation of browse quality for moose (Alces alces L.). This is due to the absence of captive moose needed for in vivo studies. Our objective was to determine if substrate drying methods alter in vitro disappearance of moose browse. In addition, we wished to determine if different drying methods affect the fiber fractions (NDF, ADF, and ADL) of the browse species being investigated.

\section{Materials and Methods}

There are a variety of modifications of the original Tilley and Terry (1963) in vitro method, e.g. the amount of substrate used, the ratio between buffer solution and inoculum, and length of digestion period. Our method was originally developed at the Swedish University of Agricultural Sciences for energy determinations of grass hay by den Braver and Eriksson (1967), and is described completely by Pehrson and Faber (1994). Briefly, it involves incubation of $0.5 \mathrm{~g}$ test substrate with $1 \mathrm{ml}$ of rumen fluid and $50 \mathrm{ml}$ of buffer solution for 72 hours. The procedure has been adopted at GWRS for browse digestibility studies in moose and roe deer (Capreolus capreolus L.) (Cederlund and Nyström 1981, Pehrson and Faber 1994).

A total of 6 in vitro trials were conducted, with 5 trials being conducted between November 1989 and May 1990, and the remaining trial in November 1993. These trials used ruminal inoculum of 6 moose harvested within the Grimsö Wildlife Research Area (GWRA) which is located in southcentral Sweden. The 6 moose used were 5 calves ( $<1$ year, 3 male \& 2 female) and 1 adult cow ( $>2$ years old) all determined to be of normal 
condition. Animal diets were not determined since we were not interested in the degree of ruminal adaptation to the plant species being tested nor on the effects of inoculum source (see Pehrson and Faber 1994). In each trial, rumen material was brought immediately to the laboratory in warmed thermos flasks, and the whole procedure from moose harvest until beginning the first phase of the in vitro digestion never exceeded 1 hour, a time interval which probably did not influence the digestion process (Schwartz and Nagy 1972). The buffer solution (den Braver and Eriksson 1967), was saturated for 1 hour in advance with $\mathrm{CO}_{2}$ and warmed to $38^{\circ} \mathrm{C}$.

The plant species tested included current-year growth of Scots pine (Pinus sylvestris L.) birch (Betula pendula Roth, Betula pubescens Ehrh.), willow (Salix spp.), and sweetgale (Myrica gale L.). Scots pine was selected because it is the most important winter browse species, both qualitatively and quantitatively, for moose in the GWRA (Cederlund et al. 1980). Birch was tested because it is extensively utilized by moose, and is quantitatively the most important component of the diet during the summer months (Cederlund et al. 1980). Willow was included because this genus is highly preferred by moose while sweetgale is not preferred (Ccderlund et al. 1980). One kg (wet wt.) of cach browse species was collected on 10 March 1989, and divided into 4 subsamples of $250 \mathrm{~g}$. Subsamples were either freeze-dried (Edwards High Vacuum International, Modulyo $4 \mathrm{~K}$ ) at $-40^{\circ} \mathrm{C}$ or conventionally oven-dried (Termaks Model T1119V) at $35^{\circ}, 60^{\circ}$ or $105^{\circ} \mathrm{C}$ for 48 hours, respectively. These temperatures were randomly selected so as to cover a wide range of drying temperatures. After drying, all samples were ground to pass a $0.5-\mathrm{mm}$ sieve.

In each trial, 2 plant species were randomly paired for testing and all drying temperatures for those 2 species were subsequently tested in the particular trial. In total, Scots pine was tested in 4 of the trials, birch in 3 , and willow and sweetgale in 2 each (Table 1). Within each trial, each subsample being tested was replicated 5 times (e.g. 5 tubes). Neutral detergent fiber, Acid Fiber (ADF), and Acid Lignin, (ADL) of the browse samples were determined

Table 1. Effect of freeze-drying $\left(-40^{\circ} \mathrm{C}\right)$ and oven-drying $\left(35^{\circ}, 60^{\circ}, 105^{\circ}\right.$ C) on the in vitro dry matter disappearance (\% of dry matter) of 4 browse species tested using moose inoculum.

\begin{tabular}{|c|c|c|c|c|c|}
\hline \multirow[b]{2}{*}{ Species } & \multirow[b]{2}{*}{ Trial no. } & \multicolumn{4}{|c|}{ Drying Method $^{1}$} \\
\hline & & Freeze & $35^{\circ} \mathrm{C}$ & $60^{\circ} \mathrm{C}$ & $105^{\circ} \mathrm{C}$ \\
\hline & & \multicolumn{4}{|c|}{$\ldots$ (\% of total dry matter disappearance) $\cdots$} \\
\hline Scots pine $e^{2}$ & 1 & 47.8 & 48.5 & 50.3 & 50.8 \\
\hline Scots pine & 2 & 30.7 & 36.6 & 32.1 & 30.6 \\
\hline Scots pine & 3 & 39.6 & 38.5 & 40.5 & 39.2 \\
\hline Scots pine & 4 & 27.1 & 24.5 & 25.8 & 28.8 \\
\hline $\mathrm{Birch}^{3}$ & 1 & 34.3 & 31.3 & 32.6 & 30.1 \\
\hline Birch & 2 & 29.0 & 29.3 & 26.6 & 24.3 \\
\hline Birch & 4 & 24.0 & 21.8 & 16.9 & 16.9 \\
\hline Willow $^{3}$ & 5 & 35.5 & 34.7 & 32.7 & 28.8 \\
\hline Willow & 6 & 27.5 & 28.6 & 23.2 & 15.0 \\
\hline Sweetgale $^{3}$ & 5 & 21.4 & 21.6 & 21.2 & 15.9 \\
\hline Sweetgale & 6 & 18.8 & 22.8 & 19.2 & 16.5 \\
\hline
\end{tabular}

All column figures represent means of $\mathrm{a}=5$

${ }^{2}$ Two-factor ANOVA analysis of Scots pine, all trials combined, drying method not significantly different $(P=0.28, \mathrm{df}=3)$

${ }^{3}$ Two-factor ANOVA analysis of birch, willow, and sweetgale, all trials combined for each species respectively, drying method significantly different $(P<0.0001, \mathrm{df}=3$ )
Table 2. Effect of freeze-drying $\left(-40^{\circ} \mathrm{C}\right)$ and oven-drying $\left(35^{\circ}, 60^{\circ}, 105^{\circ}\right.$ C) on the neutral detergent fiber (NDF), acid detergent fiber (ADF), and acid detergent lignin (ADL) concentration (\% of dry matter) of 4 browse species.

\begin{tabular}{|c|c|c|c|c|c|}
\hline \multirow{2}{*}{ Species } & & \multicolumn{4}{|c|}{ Drying Method } \\
\hline & & Freeze & $35^{\circ} \mathrm{C}$ & $60^{\circ} \mathrm{C}$ & $105^{\circ} \mathrm{C}$ \\
\hline & & \multicolumn{4}{|c|}{$-1 \%$ of total dry matter $)$} \\
\hline \multirow[t]{3}{*}{ Scots pine } & NDF & $54.30^{1} \mathrm{a}$ & $50.33 \mathrm{~b}$ & $51.86 \mathrm{~b}$ & $48.58 \mathrm{c}$ \\
\hline & $\mathrm{ADF}$ & $33.61 \mathrm{a}$ & $36.64 \mathrm{a}$ & $34.97 \mathrm{a}$ & $36.15 a$ \\
\hline & $\mathrm{ADL}$ & 11.41 & 13.34 & 13.09 & 13.73 \\
\hline \multirow[t]{3}{*}{ Birch } & $\mathrm{NDF}$ & $45.28 \mathrm{a}$ & $44.78 \mathrm{a}$ & $40.73 b$ & $34.34 \mathrm{c}$ \\
\hline & $\mathrm{ADF}$ & $39.96 \mathrm{a}$ & $41.69 \mathrm{ab}$ & $44.35 b d$ & $46.98 \mathrm{~cd}$ \\
\hline & $\mathrm{ADL}$ & 22.04 & 22.38 & 24.90 & 27.36 \\
\hline \multirow[t]{3}{*}{ Willow } & $\mathrm{NDF}$ & $46.49 \mathrm{a}$ & $46.02 a$ & $35.88 \mathrm{a}$ & $35.88 \mathrm{a}$ \\
\hline & ADF & $41.95 \mathrm{a}$ & $42.57 \mathrm{a}$ & 45.15ab & $48.92 b$ \\
\hline & $\mathrm{ADL}$ & 18.68 & 18.12 & 20.60 & 22.63 \\
\hline \multirow[t]{3}{*}{ Sweetgale } & NDF & $43.85 \mathrm{a}$ & $43.92 \mathrm{a}$ & $43.35 \mathrm{a}$ & $36.54 b$ \\
\hline & $\mathrm{ADF}$ & $42.62 \mathrm{a}$ & $44.08 \mathrm{a}$ & $43.10 \mathrm{a}$ & $48.94 b$ \\
\hline & $\mathrm{ADL}$ & 26.38 & 27.64 & 28.43 & 30.69 \\
\hline
\end{tabular}

${ }^{1}$ Row means with different letters differ $(P<0.05)$.

using the sequential techniques described by Van Soest (1963) and Van Soest and Wine (1967).

The effects of drying methods on Dry Matter Disappearance (IVDMD) estimation of the 4 browse species were tested using a 2-factor ANOVA (StatView 1992). Differences in Neutral Fiber (NDF) and ADF within each browse species were tested using a one-factor ANOVA (StatView 1992).

\section{Results and Discussion}

Significant differences in IVDMD were found among drying temperatures for birch, willow and sweetgale $(P<0.0001$, Table 1). In vitro dry matter disappearance of all 3 species were affected in a similar manner. Although freeze-drying and oven-drying at $35^{\circ} \mathrm{C}$ did not greatly impact IVDMD, oven-drying above $35^{\circ}$ C depressed IVDMD by $12-48 \%$ in the 3 browses. Scots pine was the exception, as there were no significant differences in the IVDMD due to different drying method ( $P=0.28$, Table 1).

Furthermore, analyses of NDF, ADF, and ADL of the browse species showed that different drying methods significantly affect concentrations of fiber fractions (Table 2). Neutral detergent fiber was significantly $(P<0.05)$ reduced at drying temperatures greater than $35^{\circ} \mathrm{C}$ for all species tested; conversely, ADF was significantly $(P<0.05)$ elevated at drying temperatures greater than $35^{\circ} \mathrm{C}$ for all species except of Scots pine. The trend in ADL was similar to ADF, with all species showing elevated ADL at drying temperatures greater than $35^{\circ} \mathrm{C}$, including Scots pine.

Our results suggest that in the browse samples we tested, IVDMD was depressed in those that were oven-dried above $35^{\circ} \mathrm{C}$. This is in accordance with earlier research (Acosta and Kothmann 1978, Engels et al. 1981, Burritt et al. 1988) which indicated how different drying methods can affect fiber fractions of samples being nutritionally evaluated. Drying temperatures above $25^{\circ} \mathrm{C}$ often result in nonenzymatic browning reactions (Hodge 1953). This results in a substance Van Soest (1965) terms artifact lignin, which depresses IVDMD.

In agreement with previous research (Burritt et al. 1988, Nastis and Malechek 1988), the changes in IVDMD and fiber fractions 
due to drying method were large enough in this study to indicate that this is a potentially serious source of error which needs to be considered when performing nutritional studies using IVDMD. Our results suggest that freeze-drying is a preferable drying method, and should be used to increase accuracy of IVDMD estimates.

\section{Literature Cited}

Acosta, R.A., and M.M. Kothmann. 1978. Chemical composition of esophageal-fistula forage samples as influenced by drying method and salivary leaching. J. Anim. Sci. 47:691-698.

Braver, E. den, and S. Eriksson. 1967. Determination of energy in grass hay by in vitro methods. Lantbrukshögskolans Annaler 33:751-765.

Burritt, E.A., J.A. Pfister, and J.C. Malechek. 1988. Effect of drying method on the nutritive composition of esophageal fistula forage samples: influence of maturity. J. Range Manage. 41:346-349.

Cederlund, G., H. Ljungqvist, G. Markgren, and F. Stålfelt. 1980. Foods of moose and roe deer at Grimsö in central Sweden - results of rumen content analyses. Swedish Wildlife Research, Viltrevy 11:169-247.

Cederlund, G., and A. Nyström. 1981. Seasonal differences between moose and roe deer in ability to digest browse. Holarc. Ecol. 4:59-65.
Engles, E.A.N., H.O. de Waal, L.C. Biel, and A. Malan. 1981. Practical implications of the effect of drying and treatment on nitrogen content and in vitro digestibility of samples collected by oesaphogeally fistulated animals. S. Afr. J. Anim. Sci. 11:247-254.

Hodge, J.E. 1953. Chemistry of browning reactions in model systems. J. Agr. Food Chem. 1:928-941.

Nastis, A.S., and J.C. Malechek. 1988. Estimating digestibility of oak browse for goats by in vitro techniques. J. Range Manage. 41:255-258.

Pehrson, $\AA$, and W.E. Faber. 1994. Individual variation of in vitro dry matter digestibility in moose. J. Range Manage. 47:392-394.

Schwartz, C.C., and J.G. Nagy. 1972. Maintaining deer rumen fluid for in vitro digestion studies. J. Wildl. Manage. 36:1341-1343.

StatView, 1992. Abacus Concepts, StatView. Abacus Concepts, Inc., Berkeley, Calif.

Tilley, J.M.A., and R.A. Terry. 1963. A two-stage technique for the in vitro digestion of forage crops. J. Brit. Grass. Soc. 18:104-111.

Van Soest, P.J. 1963. Use of detergents in the analysis of fibrous feeds. II. A rapid method for the determinination of fiber and lignin. J. Assoc. Off. Anal. Chem. 46:829-835.

Van Soest, P.J. 1965. Use of detergents in the analysis of fibrous feeds. III. Study of effects of heating and drying on yield of fiber and lignin in forages. J. Assoc. Off. Anal. Chem. 48:785-790.

Van Soest, P.J., and R.H. Wine. 1967. Use of detergents in the analysis of fibrous feeds. IV. Determination of plant cell-wall constituents. J. Assoc. Off. Anal. Chem. 50:50-55. 